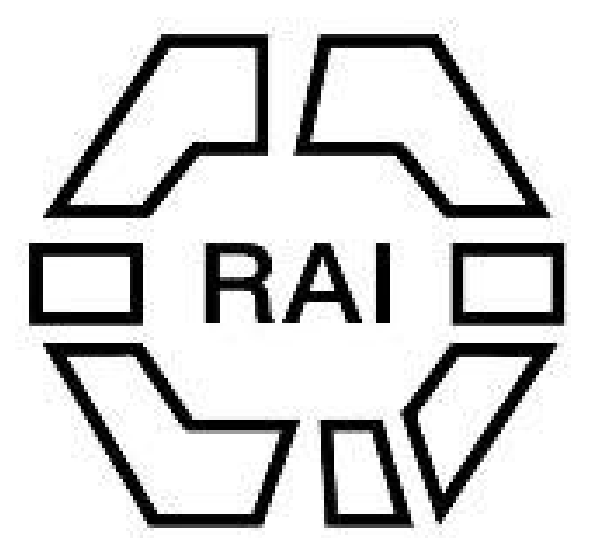

\title{
WILEY
}

\section{The Clan-Ancestor in Animal Form as Depicted on Ancient Pottery of the Peruvian}

Coast

Author(s): T. A. Joyce

Source: Man, Vol. 13 (1913), pp. 113-117

Published by: Royal Anthropological Institute of Great Britain and Ireland

Stable URL: http://www.jstor.org/stable/2787420

Accessed: 27-06-2016 07:44 UTC

Your use of the JSTOR archive indicates your acceptance of the Terms \& Conditions of Use, available at

http://about.jstor.org/terms

JSTOR is a not-for-profit service that helps scholars, researchers, and students discover, use, and build upon a wide range of content in a trusted digital archive. We use information technology and tools to increase productivity and facilitate new forms of scholarship. For more information about JSTOR, please contact support@jstor.org.

Royal Anthropological Institute of Great Britain and Ireland, Wiley are collaborating with JSTOR to digitize, preserve and extend access to Man 


\section{ORIGINAL ARTICLES.}

Peru : Religion. With Plate H.

Joyce.

The Clan-Ancestor in Animal Form as depicted on Ancient Pottery of the Peruvian Coast. By T. A. Joyce, M.A.

Remarkably little is known from literary sources concerning the manners and customs of the early inhabitants of the Peruvian coast. The archæological remains from this district, however, far outnumber those from any other region of South America, and those relating to a period some centuries before the Inca conquest of the coast belong to a very high order of craftsmanship. This is particularly the case with the pottery, and the habit of delineating in moulded or painted form the men and women of the time with their dress and ornaments enables us to reconstruct to a certain extent the local ethnography. The most advanced pottery, to speak artistically, falls into two groups, associated respectively with the district of Truxillo and the valley of Nasca. The two schools show many similarities, and were, I believe, contemporary, but striking differences exist. The Truxillo potter excelled in modelling, and his painting, though free and bold, was in monochrome. At Nasca moulded ware was rare, and the decoration, though less free and more conventionalised than at Truxillo, had developed in the direction of colour. The colours (in slip) are rich and varied, and include, besides black and white, red, pink, orange, yellow, buff, and grey. The tendency of the Nasea potter to conventionalise renders some of the designs difficult to understand, but the underlying connection with the Truxillo school enables us in some cascs to fathom his meaning, as the following small point will show. In a series of thirty-four Nasca rases recently acquired by the British Museum, three illustrate the personage shown in Fig. 1. This figure requires a little explanation. The first tning that strikes the eye is a large face wearing a mouthmask and a turban-like headdress furnished in front with a small face. Less obvious are two profile faces facing upwards, placed on either side at the level of the eyes. On each side of the main face is a pendant ear-ornament, terminating in a face. " ${ }^{*}$ the left are seen the two hands of the personage depicted, grasping a club, while to the right stands the body, clad in a fringed tunic. The artist has exaggerated the dimensions of the face (as the most important feature) beyond all proportion, and has been forced by limitations of space to adopt this peculiar arrangement of body and limbs. Across the top of the body, and extending to the right, is a kind of cloak with engrailed edges, which give it a "caterpillary" effect; the cloak terminates in a head with projecting tongue and two hands. This cloak is also somewhat exaggerated, being, as I hope to show, an important feature, and I would, in this connection, call attention to the line of connected dots down the centre. The fact that this personage, with the same attributes, is shown with very little variation on three out of a series of thirty-four vases, implies that he is at least a character of local importance.

To turn now to the Truxillo district, one of the most frequent designs on the painted pots of that region is what $I$ interpret as a ceremonial dance. In a collection of 250 vases from the Chicama Valley, presented by Mr. Van den Bergh to the British Museum, more than thirty pots bear this design, which, in one of the finest specimens appears as Fig. 2. This figure shows plainly the headdress, consisting of the skin of a small cat-like animal, invariably worn by the dancers, as well as the peculiar bifid object which they are inevitably represented as carrying. In Fig. 2 this object looks like a pair of shears, but in most cases (as in Plate H) the points bend over in the same or opposite directions, and suggest a plant with two shoots or leaves. In most cases the dancers wear animal masks and dresses, and

* This tendency to multiply faces is typical of Nasca art, and constitutes an important link with the mysterious monolith found at Chavin de Huantar, in the highlands far to the north.

[ 113 ] 


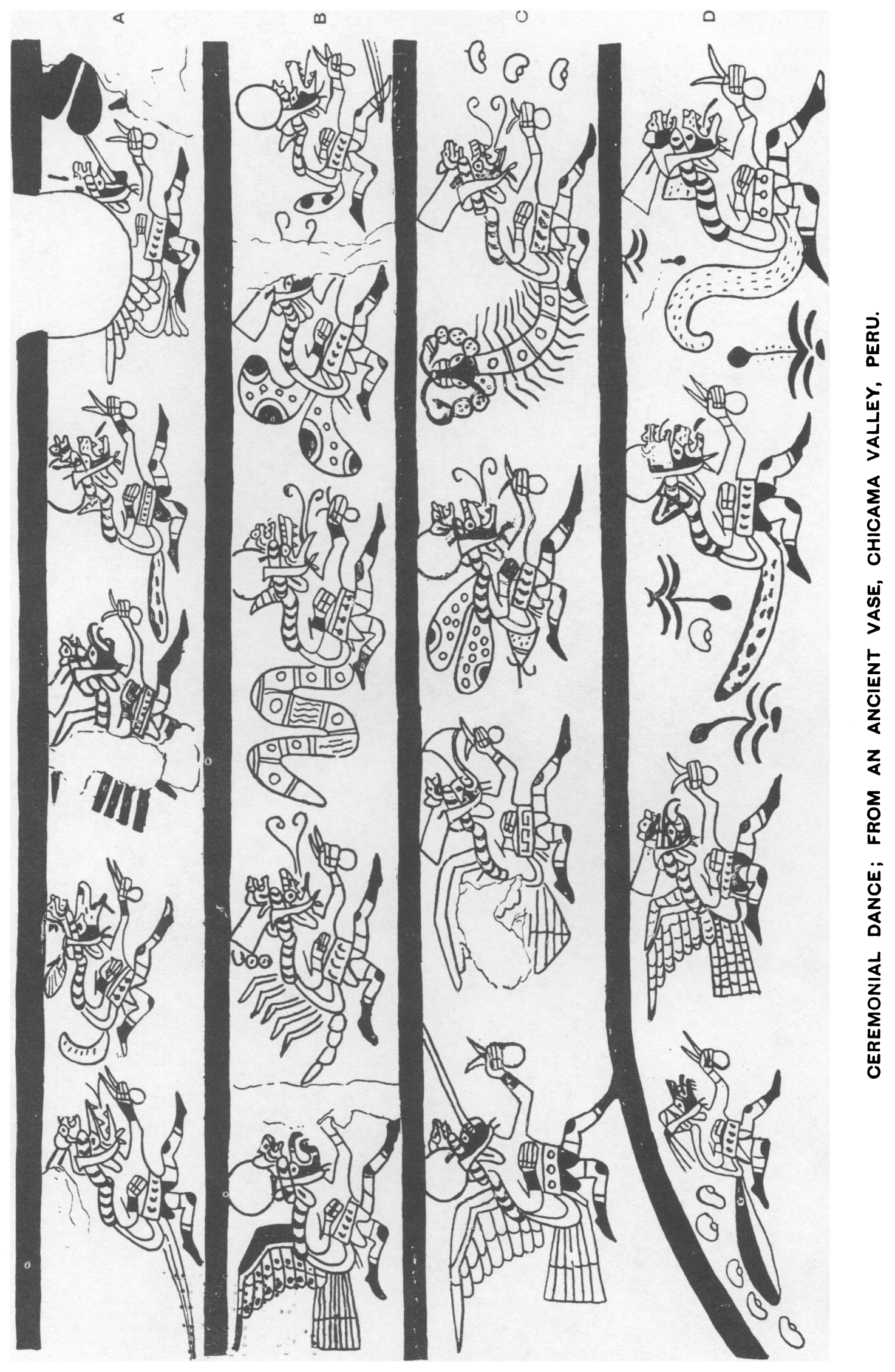



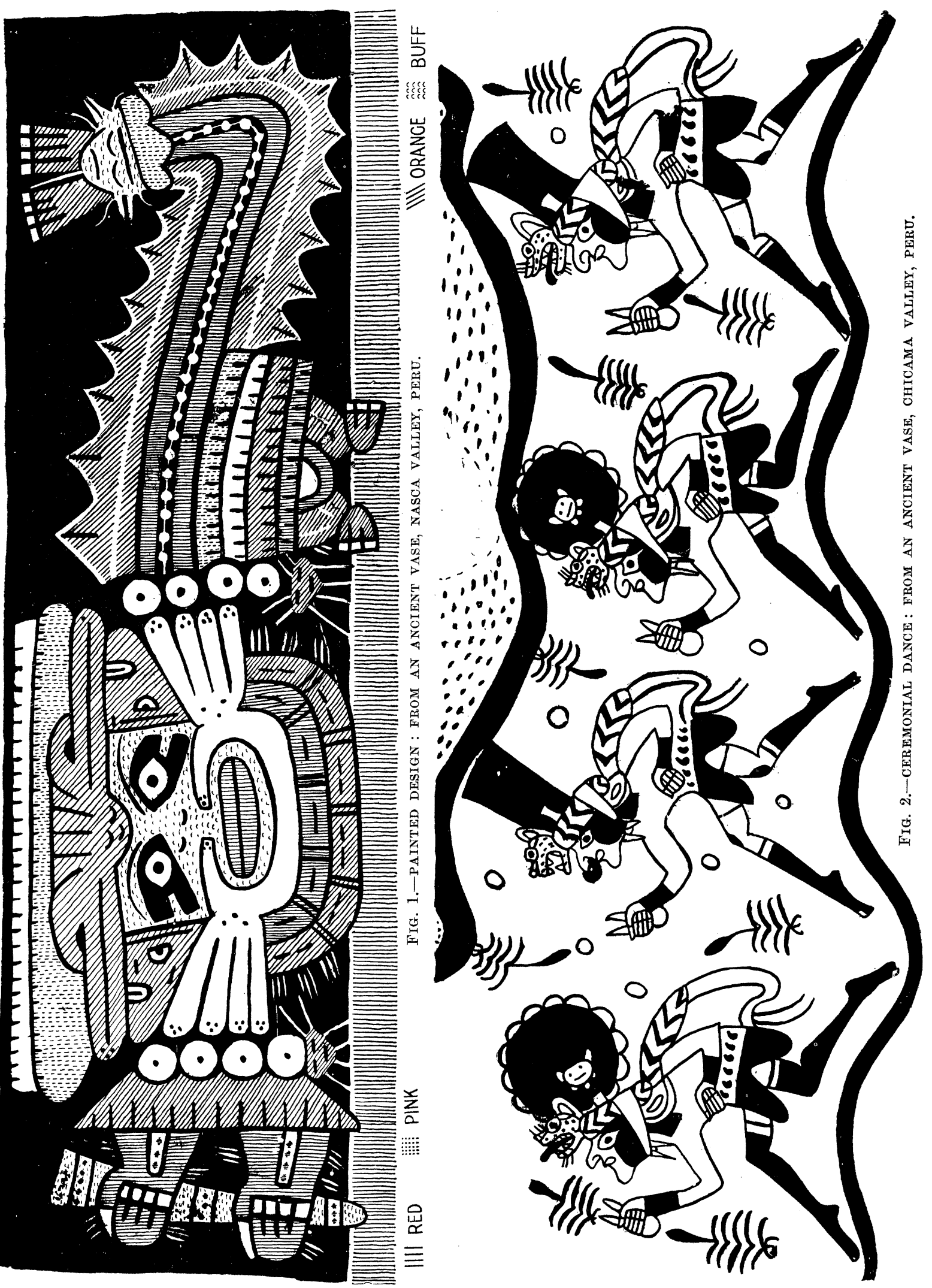
I have figured one such finely-executed scene in my South American Archaology, Fig. 15, p. 155 ; but the most elaborate representation of this scene occurs on a vase, also one of the Van den Bergh collection, the design of which is shown on the accompanying Plate H. Owing to their conventional nature, the animals are not easy to identify. In row $A$, No. 1 , and row $C$, No. 4 , we have a bird with a long bill, probably a humming-bird ; $\mathrm{A}, 2$, and $\mathrm{D}, 2$, are probably jaguars ; $\mathbf{A}, 3$, may be a hawk; $\mathbf{A}, 4$, is certainly a deer (the peculiar tail, and the lolling tongue similar to that of the Mexican mazatl sign, enable us to identify it by comparison with other Peruvian vases); A, 5, may be a lizard ; B, 1, doubtful ; B, 2, a butterfly ; B, 3, a snake; $\mathrm{B}, 4$, a scorpion; $\mathrm{B}, 5$, and $\mathrm{D}, 3$, condors ; C, 1 , a centipede ; C, 2, a wasp ; C, 3, a pelican (also by comparison with other pots); D, 1, a wild cat; and $\mathrm{D}, 4$, a fox.

It is to the first figure in row $\mathrm{C}$, the centipede, that I would call attention, as affording an interpretation of the figure on the Nasca vase. Apart from the fact that the body of the animal is arranged in the same position relative to the human figure, we have the realistic legs of the Truxillo representation paralleled by the "caterpillary" projections of the Nasca picture, the nippers and head in the former by the face and hands of the latter, the circles marking the body-segments in the former by the row of connected dots in the latter. I would suggest, therefore, that the Nasca vase represents a human figure in centipede dress.

Before considering the meaning of the costume, I should like to trace shortly the centipede motive in Nasca art; the illustrations which follow are taken from

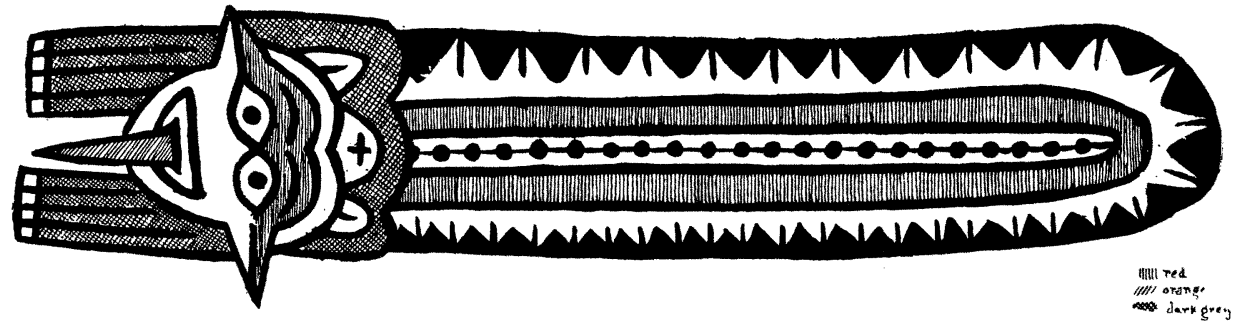

FIG. 3.-FIGURE OF CENTIPEDE: FROM AN ANCIENT VASE, NASCA VALLEY, PERU.

the small series of thirty-four vases mentioned above, a fact which emphasizes the importance of this animal in the Nasca valley. Fig. 3 shows the centipede alone, utilised as a single band round a beaker-shaped vase. Fig. 4 gives the body of the animal forming an endless ornamental band in conjunction with human faces; in this representation the legs have been elaborated, but the row of connected dots down the centre of the body persists. In Fig. 5, again we have the body as an endless band, in connection with the figures of mice; here it is so conventionalised as to render recognition difficult when taken by itself, but in connection with the former figures I think its identity is beyond doubt.

As I have said above, we know practically nothing of the customs and beliefs of the coast peoples, but it is fair to argue by analogy from what we know of the inlanders, for this reason. It is obvious to one who has studied the archæology of South America that the cultured peoples of the Andes and west coast possessed a common psychology which manifested itself in social systems, religions, and art, which were closely akin. Without this kinship, indeed, the rapidity and permanence of the Inca conquest were, considering the geographical conditions, unthinkable. The Inca imposed sun-worship, it is true, but were satisfied that offerings should be made to their own god at stated festivals; for the rest the subject tribes were allowed to worship their own deities; and the latter were even allowed to participate in the great sun-festivals at the capital. Beyond a mere ceremonial admission of the priority 
of the sun as a deity nothing was expected of the vassals, and in the mind of the ordinary native the local huaca exercised far greater control over his everyday actions and fortunes. One of the most important sides of the Peruvian religion everywhere

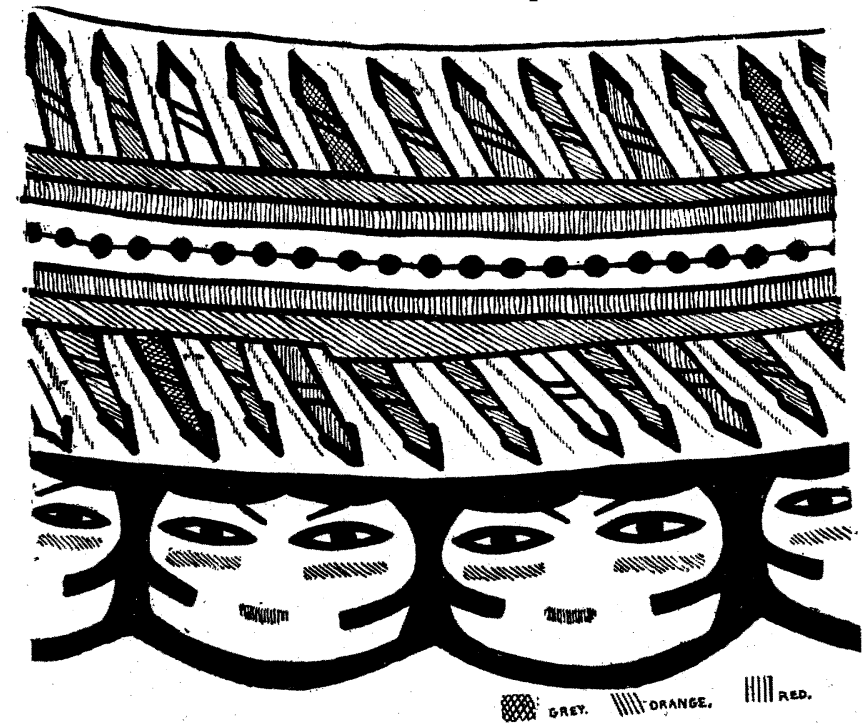

Fig. 4.-CENTIPEDE MOTIVE : FROM AN ANCIENT VASE, NASCA VALLEY, PERU. was the worship of the ancestor of the clan (ayllu), and an equally important feature of the mytho$\operatorname{logy}$ was the tendency for these minor deities to assume animal shape. In fact in many of the legends, as in the legends of British Columbia, the human and animal aspects of the mythological individual are impossible to distinguish. The clan was an important element in the Peruvian social system, at any rate throughout the highlands; there is evidence that the clans were segregated in different quarters of important cities, such as at Cuzco, and the arrangement of the coastal buildings into distinct wards, each surrounded by its own wall, which is so noticeable at Truxillo, suggests that a similar system prevailed on the seaboard. According to a widespread creation-myth (I quote from Molina, whose account is especially full), "in Tia-

" huanaco the Creator

" began to raise up

" the people and na-

" tions that are in

" that region, making

" one of each nation

" of clay, and paint-

" ing the dresses that

" each one was to

" wear. . . . He

" gave life and soul

" to each one... .

" and ordered that

" they should pass

" under the earth.

"Thence each nation

" came up in the

" places to which he

" ordered them to go. Thus they say that some issued from caves, others from

" hills, others from fountains, others from the trunks of trees. . . . Thus each

" nation uses the dress with which they invest their huaca; and they say that the [ 116 ] 
" first that was born from that place was there turned into stones, others say that " the first of their lineages (ayllu) were turned into falcons, condors, and other " animals and birds. Hence the huaca they use and worship are in different "shapes."

As supplementary to the above may be mentioned the statement of Arriaga, that in a certain village the discovery was made of a stone figure of a falcon supported on a silver plate and surrounded by four human mummies richly dressed. The falcon was said to be the huaca of the ayllu, and the mummies were stated to be those of its sons, the progenitors of the ayllu; as such they were objects of local worship.

A passage from Garcilasso de la Vesga, himself of Inca descent, taken with the above, will, I think, explain the use of animal costumes. $\mathrm{He}$ is writing of the great feast of the Sun, Yntip Raymi, at Cuzco, and of the part played therein by the vassal tribes: "The Curaças (local chiefs) came in all the splendour they could " afford. Some wore dresses adorned with bezants of gold and silver, with the same "fastened as a circlet round their headdresses. Others came in a costume neither" " more nor less than that in which Hercules is painted, wrapped in the skins of " lions with the heads fixed over their own. These were the Indians who claimed " descent from a lion. Others came attired in the fashion that they paint their " angels, with great wings of the bird they call cuntur (condor). . . . These " are the Indians who declare that they are descended from a cuntur. The Yunca " (coast-dwellers) came attired in the most hideous masks that can be imagined, and " they appeared at the feasts making all sorts of grimaces. . . ."

One feature of these animal dresses deserves mention, viz., that they constituted almost the only kind of personal property known under the communistic system which prevailed, at least under the Inca régime, in Peru. The personal fetishes belonging to a man were buried with him, but the family fetishes (conopa) and the dresses worn in the festivals held in honour of the huaca, which must almost certainly be identified with these animal costumes, were inherited by the eldest son. In this respect they correspond to the animal masks and other insignia connected with the winter ceremonials of the tribes of the west coast of North America, though here inheritance is frequently-indeed, more frequently-in the female line.

The points which I wish to emphasize in the above short paper may be summarised as follows. The importance of the cult of the clan-ancestor throughout Peru; the identification of the dance scene with animal costumes, so common in early coastal pottery, with ceremonies commemorating the huaca of the various ayllu; and the importance of the centipede as a local huaca in the valley of Nasca.

T. A. JOYCE.

Sociology : India.

Hodson.

Birth Marks as a Test of Race. By T. C. Hodson.

The Indian Government has taken advantage of the recent Census opera.

tions to order enquiries into the prevalence of blue patches on the lower sacral region of infants, which Herr Baelz believes are found exclusively amongst persons of Mongolian race. The anthropometric data, examined in 1901 by and under the direction of the late Sir Herbert Risley, sbowed that there is a Mongoloid element in the population of the delta of the Ganges and its tributaries from the confines of Bihar to the Bay of Bengal, from the Himalayas on the north and the province of Assam on the east down to Orissa, with the hilly country of Chota Nagpur and Western Bengal as a western limit. On the northern and eastern frontier India marches with the great Mongolian region, but the intervention of the great physical barrier of the Himalayas offers an impassable obstacle to the southward extension of 